\title{
Diffüz Alopesili Kadınlarda "Dijital Fototrikogram" ile "Darı Ekstresi, Buğday Tohumu Yağı, L-sistin, Kalsiyum Pantotenat" Formulasyonunun Etkisinin Değerlendirilmesi
}

Özel Batman Dünya Hastanesi, Deri ve Zührevi Hastalıklar Bölümü, Batman, Türkiye ${ }^{*}$ Gazi Üniversitesi Tıp Fakültesi Dermatoloji Anabilim Dalı, Ankara, Türkiye

\section{Özet}

Amaç: Bu çalıșmada kliniğimize bașvuran telogen effluviumlu kadınlarda "Dijital Fototrikogram" (Trichoscan) ile "Darı Ekstresi, Buğday Tohumu Yağı, L-Sistin, Kalsiyum Pantotenat" formulasyonunun etkisinin değerlendirilmesi amaçlandı.

Gereç ve Yöntem: Ocak 2008-Kasım 2008 tarihleri arasında, Gazi Üniversitesi Tıp Fakültesi Dermatoloji Polikliniği'ne diffüz saç dökülmesi șikayetiyle bașvuran kadın hastalar değerlendirildi. Hastalara dijital fototrikogram testi frontal ve oksipital bölgelerde uygulanarak anagen ve telogen oranları saptandı. Klinik görünüm ve dijital fototrikogram sonucu telogen effluvium tipi diffüz alopesi ile uyumlu, 18-50 yașları arasında 53 kadın hasta çalıșma kapsamına alındı. Hastalara darı ekstresi 140 mg, buğday tohumu yağı 271 mg, L-sistin 2 mg, kalsiyum pantotenat 10 mg'dan olușan kapsül günde $3 \times 1$ dozunda, 3 ay süre ile verildi. Çalıșma kapsamına alınan hastaların tedaviye yanıtlarının değerlendirilmesinde günlük dökülen saç sayısı, saç çekme testi ve dijital fototrikogram kriter olarak alındı.

Bulgular: İlk değerlendirmede günlük dökülen yaklașık saç sayısı ortalaması 84,1 555,9 iken verilen 3 aylık tedaviden sonra günlük dökülen saç sayısı ortalaması $44,9 \pm 28$ olarak saptandı. Hastaların tedavi sonrasında günlük dökülen ortalama saç sayısındaki azalma istatistiksel olarak anlamlı bulundu. Hastalarımızın tedavi öncesi saç çekme testi ile tedavi sonrası saç çekme testi arasında istatistiksel olarak anlamlı farklıık saptandı. Tedavi öncesinde ortalama anagen değeri frontal bölgede $69,0 \pm 11,2$, oksipital bölgede $72,3 \pm 9,4$ olarak saptandı. Tedavi sonrasında frontal bölge anagen oranı $76,4 \pm 11,2$ 'e, oksipital bölge anagen oranı $79,9 \pm 8,6$ 'a yükseldi. Tedavi sonrasında frontal ve oksipital bölgede anagen oranındaki artma istatistiksel olarak anlamlı olarak kabul edildi.

Sonuç: Çalıșmamızda "L-sistin, kalsiyum pantotenat, buğday tohumu yağı ve darı ekstresinden olușan formulasyon"unun telogen effluvium tedavisinde etkili olduğu düșünülebilir. Ancak daha geniș alopesili hasta gruplarında plasebo kontrollü çalıșmalar gereklidir. (Türkderm 2012; 46: 78-83)

Anahtar Kelimeler: Telogen effluvium, dijital fototrikogram, L-sistin

\section{Summary}

Background and Design: In this study, we aimed to evaluate the effects of a formula composed of millet extract, wheat germ oil, calcium pantothenate and L-cystine in women with diffuse alopecia by using Digital Phototrichogram (Trichoscan).

Materials and methods: We evaluated female patients who presented to Gazi University Faculty of Medicine Department of Dermatology between January 2008 and November 2008 with the complaint of diffuse hair loss. Digital phototrichogram was performed in the frontal and occipital regions of the patients. Using this method, anagen:telogen ratios were determined. 53 female patients whose ages were between 18 and 50 and who were diagnosed as having telogen effluvium type diffuse alopecia were included in the study. The patients were given a capsule containing $140 \mathrm{mg}$ millet extract, $271 \mathrm{mg}$ wheat germ oil, $2 \mathrm{mg}$ L-cystine and $10 \mathrm{mg}$ calcium pantothenate three times a day for three months. The criteria for assessing the efficacy of the therapy included number of hair loss per day, hair pull test and digital phototrichogram.

Yazışma Adresi/Address for Correspondence: Dr. Deniz Çetinkünar, Özel Batman Dünya Hastanesi, Deri ve Zührevi Hastalliklar Bölümü, Batman, Türkiye CSM: +90 5054133697 E-posta: dkarsilayan@yahoo.com Geliş Tarihi/Received: 28.07.2011 Kabul Tarihi/Accepted: 19.09.2011

Türkderm-Deri Hastalıkları ve Frengi Arșivi Dergisi, Galenos Yayınevi tarafından basılmıștır. Turkderm-Archives of the Turkish Dermatology and Venerology, published by Galenos Publishing. 
Results: The reduction of daily average hair loss after the treatment was statistically significant. Statistically significant difference was found between the pre- and post-treatment results of the hair pull test. Before the treatment, the average anagen ratio was determined to be $69.0 \pm 11.2$ in the frontal region, and $72.3 \pm 9.4$ in the occipital region. After the treatment, the anagen ratio increased to $76.4 \pm 11.2$ in the frontal region and to $79.9 \pm 8.6$ in the occipital region. The increase in the anagen hair rate in the frontal and occipital regions after the treatment was found to be statistically significant. Conclusion: As a result, it was found that the formula composed of millet extract, wheat germ oil, L-cystine and calcium pantothenate may be effective in the treatment of telogen effluvium. However, controlled studies including larger groups of diffuse alopecia patients and placebo groups are needed. (Turkderm 2012; 46: 78-83)

Key Words: Telogen effluvium, digital phototrichogram, L-cystine

\section{Giriş}

Saç dökülmesi dermatoloji kliniklerine sık başvurma nedenidir. Saç kaybı her yaştaki kadın ve erkeği etkileyebilen, psikososyal olarak kişileri rahatsız eden bir durumdur. Saç hayatın devamı için gerekli değildir ancak kişinin imajı için çok önemlidir. Saç sayısında, yapısında ve dağılımında en küçük değişiklik hastanın doktora başvurmasına neden olur1-3.

Saç dökülmesi şikayeti ile gelen hastada doğru tanı için sistemik yaklaşım gerekmektedir. Tanı detaylı hikaye, fizik muayene, laboratuvar tetkikleri, gerekli hastalarda deri biyopsisi yanında saçın mikroskobik muayenesi ile konulabilir. Doğru tanı ve tedavinin erken başlanabilmesi açısından bu tetkikler son derece önemlidir2,4.

"Telogen effluvium" diffüz alopesi ile başvuran kadınlarda en sık görülen alopesi türüdür5,6. Telogen effluvium, kıl siklusundaki bozukluğa bağlı olarak gelişen, telogen saçların yaygın kaybı ile karakterizedir. Altta yatan pek çok nedene bağlı olabileceği gibi idiopatik de olabilir4,6. Telogen effluviumun spesifik bir tedavisi yoktur. Öncelikle altta yatan nedenin tedavisi yapılmalıdır. Hastaların çoğunda kendiliğinden geriler ve saçların yeniden gelişimi gözlenir6-9.

Saç dökülmesi tedavisinde oral olarak vitamin ve aminoasit kombinasyonundan oluşan preparatlar kullanılmaktadır. Arginin/L-arginin ve/veya sistin/L-sistin aminoasitlerinin saç gelişiminde önemli rol oynadıkları düşünülmektedir ve saç dökülmesinde önerilmektedir8.

L-sistin, kalsiyum pantotenat, darı ekstresi içeren kapsüller; tiamin, kalsiyum pantotenat, L-sistin, keratin, paraaminobenzoik asit içeren kombinasyonlar; retinol, L-sistin ve jelatin içeren preparatlar ile yapılmış klinik çalışmalar mevcuttur. Bu kombinasyonların alopesi tedavisinde etkili olduğu çeşitli çalışmalarda bildirilmiştir8,10-13. Ancak halen alopesi tedavisinde etkinlikleri ile ilgili tartışmalar devam etmektedir.

Saç dökülmesinin ve seyrinin değerlendirilmesi, tedaviye yanıtın izlenmesi için farklı metotlar kullanılmaktadır. İdeal inceleme yöntemi uygulaması kolay, tekrarlanabilir, ekonomik, non invazif olmalıdır ve kıl gelişimi ile ilgili temel parametreleri verebilmelidir14,15. Dijital imaj analizi ile epilüminesan mikroskobun bir arada kullanıldığı Dijital Fototrikogram (Trichoscan) 2001 yılında Hoffmann tarafından geliştirilmiş̧ir16,17. Geliştirilmiş yazılım programları ile 20 dakikada saç büyüme hızı, saç dansitesi, saç çapı, anagen/telogen oranı hesaplanır. Ağrısız, uygulayıcıdan bağımsız ve tekrarlanabilen bir yöntemdir 14,16-18.

Bu çalışmada telogen effluviumlu kadınlarda "Darı Ekstresi, Buğday Tohumu Yağı, L-Sistin, Kalsiyum Pantotenat" formulasyonunun saç üzerine etkisinin "Dijital Fototrikogram" (trichoscan) ile anagen/telogen oranlarını göstererek değerlendirilmesi amaçlanmıştır.

\section{Gereç ve Yöntem}

\section{Hasta Seçimi}

Bu çalışma için etik kurul onayı alındı. Ocak 2008-Kasım 2008 tarihleri arasında polikliniğimize diffüz saç dökülmesi şikayetiyle başvuran kadın hastalar değerlendirildi.
Tüm hastalardan ayrıntılı hikaye alındı. Standart hazırlanan "Saç Dökülmesi Hasta Takip Formu"na hastaların kayıtları yapıldı. Saç dökülmesinin süresi, günlük dökülen yaklaşık saç sayısı, saç dökülmesi için tedavi alıp almadığı, sistemik hastalık ve/veya alınan diğer ilaçlar, beslenme alışkanlığı, diyet, psikolojik stres, ameliyat öyküsü, hamilelik, mensturasyon ve menapoz durumları sorgulandı. Dermatolojik muayene ile alopesi tipi, yaygınlığı, lokalizasyonu belirlendi ve saç çekme testi uygulandı. Tüm hastalarda tam kan sayımı, serum demir, serum demir bağlama kapasitesi, ferritin, tiroid fonksiyon testleri değerlendirildi. Gereken olgularda ise DHEAS, serbest ve total testosteron, prolaktin, ANA ve VDRL tetkikleri istendi. Kan tetkikleri normal olarak saptanan hastalara dijital fototrikogram testi frontal ve oksipital bölgelerde uygulandı. Bu yöntemle anagen ve telogen oranları saptandı. Telogen oranının \%20 ve üzerinde olması patolojik olarak değerlendirildi. Klinik görünüm ve dijital fototrikogram sonucu diffüz alopesinin telogen effluvium tipi ile uyumlu, 18-50 yaşları arasında, kan tetkiklerinde anormallik saptanmayan 58 kadın hasta çalışma kapsamına alındı.

Hamile ve laktasyon dönemindeki hastalar, androgenetik alopesisi bulunan, hiperandrogenizm bulgusu olan, son 6 ay içerisinde saç dökülmesi nedeniyle tedavi alan ve laboratuvar tetkiklerinde anormallik saptanan hastalar çalışmaya dahil edilmedi.

Tüm hastalardan "Bilgilendirilmiş Onam" alındı. Değerlendirilme çalışmayı tamamlayan 53 hasta üzerinden yapıldı.

\section{Yöntem}

Çalışma kapsamına alınan hastaların tedavi öncesi ve sonrası değerlendirilmesinde günlük dökülen saç sayısı, saç çekme testi ve dijital fototrikogram kriter olarak alındı.

Tedavi öncesinde tüm hastaların saçlı deri frontal ve oksipital bölgesine orta hattın $2 \mathrm{~cm}$ sağına veya soluna ortasında 1,8 $\mathrm{cm}^{2}$ lik delik bulunan plak yerleştirildi. Bu delikten saçlar çıkarılarak önce kısaltıldı, sonrasında tıraşlandı. Hasta 2 gün sonra tekrar çağrıldı. Tıraşlanan bölge saçların görünebilmesi için kontrastı sağlayan, kirpik boyası olarak kullanılan Refecto Cil ${ }^{\circledR}$ (su, stearil alkol, digliseril-poliaçil-adipate-2, PEG-40 Hidrojene kastor yağı, sodyum stearil sülfat, sodyum laureth sülfat) ile boyandı. On iki dakika beklenerek tıraşlanmış saçların boyayı alması sağlandı. On iki dakika sonra bölge Actoderm ${ }^{\circledR}$ (2-propanol, lanolin, su) ile temizlendi. Henüz alan nemli iken bu bölgelerden dijital epilüminesan sistem (Griscope) ile 30 kat büyütmede dijital görüntüler alındı. Alınan görüntüler Grimed versiyon yazılım sistemi kullanılarak analiz edildi ve incelenen alandaki anagen / telogen oranı hesaplandı (Şekil 1).

Hastaların frontal bölgesinden yaklaşık 60 saç teli baş ve işaret parmakları arasında sıkıca tutularak yavaşça çekildi, epile edilen saçlar sayıldı. Altıdan fazla saçın sayılması durumunda saç çekme testi pozitif kabul edildi $(2,4,16)$ (Şekil 2).

Tedavi öncesinde hastaların günlük dökülen yaklaşık saç sayısı kaydedildi. Hastalara ilk değerlendirme ve tetkikler sonrasında darı ekstresi 140 mg, 
buğday tohumu yağı $271 \mathrm{mg}$, L-sistin $2 \mathrm{mg}$, kalsiyum pantotenat 10 mg'dan oluşan kapsülü (Priorin ${ }^{\circledR}$ ) günde $3 \times 1$ dozunda, 3 ay almaları önerildi ve her hastaya 270 kapsül ilaç teslim edildi.

Üç aylık tedaviden sonra hastalar tekrar çağrıldı. Frontal ve oksipital bölgede tedavi öncesi dijital olarak tetkik edilen alanlara yeniden dijital fototrikogram uygulandı. Alınan görüntülerde tedavi sonrası anagen ve telogen oranları hesaplandı.

Tedavi sonunda frontal bölgede saç çekme testi tekrarlandı ve günlük dökülen yaklaşık saç sayısı sorgulandı. Saptanan anagen değerleri, saç çekme testi durumu, dökülen saç sayısı tedavi öncesi değerler ile karşılaştırıldı. Hastaların frontal ve oksipital bölgelerinde hesaplanan anagen değerlerinde \%20 ve üzerinde artma varsa çok iyi cevap, \%1019,9 artma iyi cevap, \%1-9,9 artma orta cevap, değişiklik olmaması ve anagende azalma cevapsız olarak değerlendirildi.

Ayrıca hastalardan tedavinin saç dökülmesi ve tırnak yapısı üzerine olan etkisini 0-4 arasında derecelendirilmeleri istendi. 0 etkisiz, 1 zayı f etkili, 2 orta etkili, 3 iyi etkili, 4 çok iyi etkili olarak tanımlandı.

Tedaviyle ilgili hastalarımız tarafından bildirilen yan etkiler hasta takip formuna kaydedildi.

\section{İstatistiksel Analiz}

İstatistiksel olarak değerlendirme "Statistical Programme for Social Sciences 11.5" (SPSS 11.5) programı ile yapıldı. Sürekli ve kesikli değişkenlerin dağılımının normale yakın olup olmadığı Shapiro Wilk testi ile araştıııldı. Tanımlayıcı istatistikler sürekli ve kesikli değişkenler için ortalama \pm standart sapma veya ortanca (minimum-maksimum) olarak, nominal değişkenler ise vaka sayısı ve (\%) şeklinde gösterildi. Bağımsız gruplar arasında ortanca değerler yönünden farkın önemliliği, bağımsız
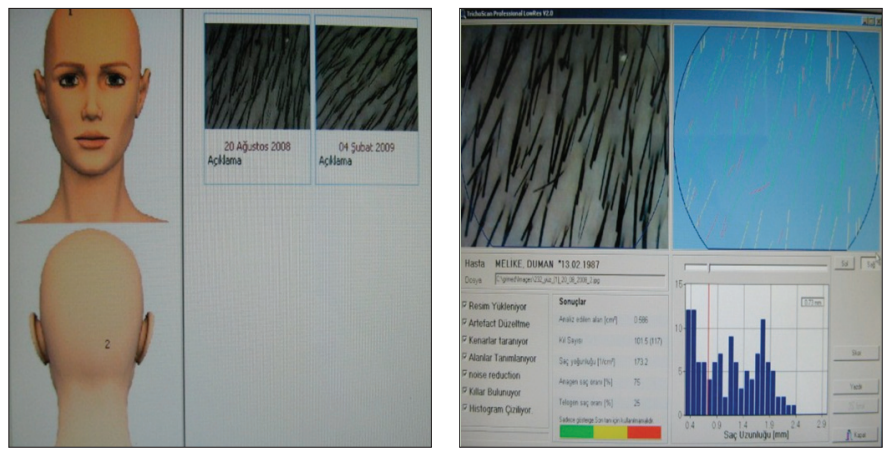

Şekil 1. Analiz

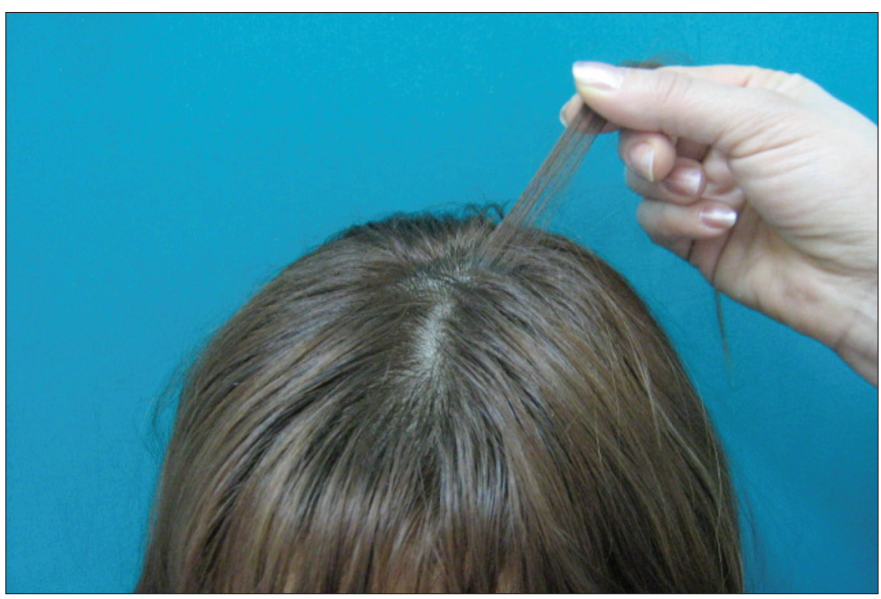

Şekil 2. Saç çekme testi uygulaması (Pull test) grup sayısı iki olduğunda, Mann Whitney U testi ile ikiden fazla bağımsız grubun olduğu durumlarda ise Kruskal Wallis testi ile araştıııldı. Ikiden fazla bağımsız grup arasında ortalamalar yönünden farkın önemliliği ise Tek Yönlü Varyans Analizi (One-Way ANOVA) ile değerlendirildi. Tedavi öncesi ve tedavi sonrası anagen, telogen ve günlük saç kaybı düzeyleri arasında istatistiksel olarak anlamlı değişimin olup olmadığı Wilcoxon İşaret testi ile değerlendirildi. Tedavi öncesi ve tedavi sonrası saç çekme testi (pull test) oranlarındaki değişimin önemliliği ise McNemar Testi ile incelendi. Nominal değişkenler Fisher'in Tam Sonuçlu Olasılık Testi ile değerlendirildi. Sürekli değişkenler arasındaki doğrusal ilişkinin önemliliği Spearman'ın korelasyon testi ile araştı ıldı. p>0,05 olan değerler anlamsı, $p<0,05$ olan değerler anlamlı kabul edildi.

\section{Bulgular}

Çalışmamıza 58 kadın hasta kabul edildi. İki hasta tedaviyi yarıda bıraktığı için çalışma dışı bırakıldı. Üç hasta ise kontrol saç testi yaptırmak istememeleri nedeniyle çalışmadan çıkarıldı. Çalışma 53 hasta üzerinden değerlendirildi.

Çalışmamızda yaş ortalaması 33,2ะ10,2 (18-50) olarak bulundu.

Hastaların 2 ay ile 10 yıl arasında değişen sürede saç dökülmesi şikayetleri vardı. Saç dökülme süresi ortalaması 27,32 228,01 ay, ortancası 12 ay (min:2, maks: 120 ay) olarak bulundu.

24 hasta $(\% 45,3)$ daha önce saç dökülmesi nedeniyle tedavi almışlardı. Bu tedaviler kısa süreli kullanılan saç kozmetik ürünleri, saç losyonları, şampuan veya kısa süreli oral vitamin kombinasyonları tarzında tedavilerdi. Son 6 aydır saç dökülmesi için tedavi alan hastamız yoktu. Tedavi alan hastaların 6'sı (\%25) aldıkları tedaviden fayda gördüklerini ancak sonrasında şikayetlerinin tekrarladığını ifade ettiler.

Tüm hastaların hemoglobin, tiroid fonksiyon testleri normal sınırlardaydı. Hastaların ferritin düzeyleri 5,60 ng/ml-156,31 ng/ml arasında değişmekteydi. (Ferritin normal değerleri: 4,63-204 ng/ml).

Illk değerlendirmede günlük dökülen saç sayısı ortalaması 84,1 \pm 55,9 iken verilen 3 aylık tedaviden sonra günlük dökülen saç sayısı ortalaması 44,9 \pm 28 olarak saptandı. Günlük dökülen saç sayısı açısından tedavi öncesi ve sonrası istatistiksel olarak anlamlı farklılık bulundu $(p<0,05)$.

Hastalarımızın tedavi öncesi saç çekme testi ile tedavi sonrası saç çekme testi arasında istatistiksel olarak anlamlı farklılık saptandı. Çekme testi pozitif olma oranı tedavi öncesi \%54,7 iken tedavi sonrası \%5,7'ye geriledi $(p<0,05)$ (Tablo 1).

Dijital fototrikogram ile saptanan tedavi öncesi ve sonrası frontal ve oksipital bölge anagen-telogen ortalama değerleri tablo 2'de gösterilmiştir. Anagen oranında artma saptanan bir hastamızın dijital fototrikogram görüntüsü Şekil 3, 4'de sunulmuştur. Frontal bölgede ve oksipital bölgede tedavi sonrasında anagen oranındaki artma ve buna paralel olarak telogen oranındaki azalma istatiksel olarak anlamlı bulundu $(p<0,05)$. Frontal ve

Tablo 1. Tedavi öncesi ve sonrası saç çekme testi

\begin{tabular}{|c|c|c|c|c|c|}
\hline \multirow[t]{2}{*}{ Çekme testi } & \multicolumn{2}{|c|}{ Tedavi öncesi } & \multicolumn{2}{|c|}{ Tedavi sonrası } & \multirow[t]{2}{*}{$p$} \\
\hline & Sayı & Yüzde & Sayı & Yüzde & \\
\hline Pozitif & 29 & 54,7 & 3 & 5,7 & $p<0,001^{a}$ \\
\hline Negatif & 24 & 45,3 & 50 & 94,3 & $p<0,001 a$ \\
\hline
\end{tabular}


oksipital bölge arasında tedaviye verilen cevap açısından anlamlı fark saptanmadı $(p>0,05)$.

Hastaların frontal ve oksipital bölgelerde hesaplanan anagen değerlerinde tedaviden sonra \%20 ve üzerinde artma olması çok iyi cevap, \%10-19,9 artma iyi, \%1-9,99 artma orta cevap, değişiklik olmaması ve anagen düzeyinde azalma cevapsız olarak tanımlandı. Tedavi sonunda frontal bölge anagen değerlerine göre 15 hastada $(\% 28,3)$ çok iyi, 8 hastada $(\% 15,1)$ iyi, 13 hastada $(\% 24,5)$ orta yanıt gözlenirken 17 hastada $(\% 32,1)$ tedaviye yanıt gözlenmedi. Tedaviye cevap vermeyen 17 hastanın 2 'sinde $(\% 3,8)$ anagen oranlarında değişiklik olmadı, $15^{\prime}$ inde $(\% 28,3)$ ise anagen oranlarında azalma saptandı.

Oksipital bölge anagen oranları değerlendirildiğinde 15 hastada $(\% 28,3)$ çok iyi, 11 hastada $(\% 20,8)$ iyi, 11 hastada $(\% 20,8)$ orta cevap gözlendi. 16 hastada $(\% 30,2)$ ise tedaviye yanıtsız idi. Tedaviye cevap vermeyen bu hastaların 3 ünde $(\% 5,7)$ tedavi sonrasında anagen oranı değişmedi, 13 ünde $(\% 24,5)$ ise anagen oranlarında azalma saptandı.

Hasta memnuniyeti değerlendirilmesinde hastaların verilen tedavinin etkisini 0-4 arasında derecelendirmeleri istendi. 0 etkisiz, 1 zayıf, 2 orta, 3 iyi, 4 çok iyi olarak tanımlandı. Saç dökülmesi şikayeti olan 53 hastanın 8'i $(\% 15,1)$ tedaviyi saç dökülmesinde çok iyi; 23'ü $(\% 43,4)$ iyi; 14'ü $(\% 26,4)$
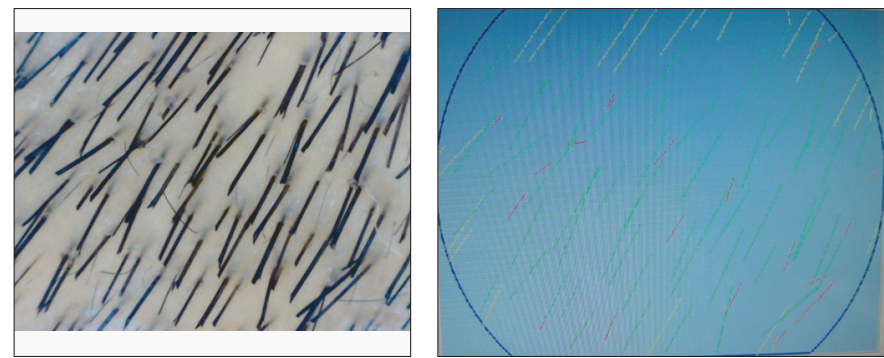

Şekil 3. Tedavi öncesi hastamızın dijital fototrikogram görüntüsü anagen $\% 77$
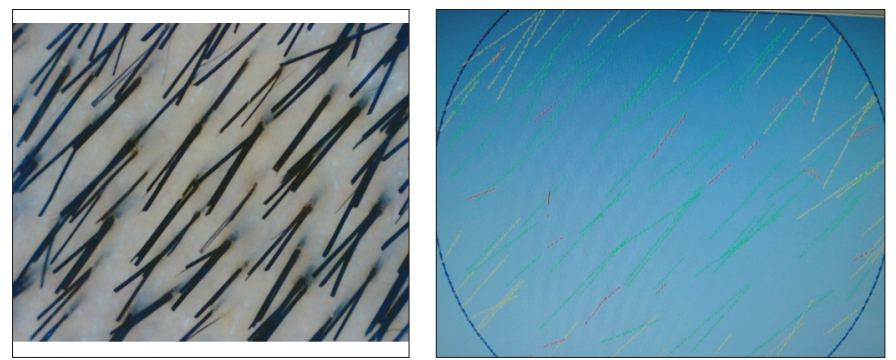

Şekil 4. Tedavi sonrası hastamızın dijital fototrikogram görüntüsü anagen $\% 93$

Tablo 2. Frontal ve oksipital bölgede tedavi öncesi ve tedavi sonrası anagen ve telogen oranları

\begin{tabular}{|l|c|c|c|}
\hline Değişkenler & Tedavi öncesi & Tedavi sonrası & $\mathbf{p}$ \\
\hline Frontal Bölge & & & \\
\hline Anagen \% & $69,0 \pm 11,2$ & $76,4 \pm 11,2$ & $<0,001^{\mathrm{a}}$ \\
\hline Telogen \% & $30,9 \pm 11,2$ & $24,2 \pm 11,5$ & $<0,001^{\mathrm{a}}$ \\
\hline Oksipital Bölge & & & \\
\hline Anagen \% & $72,3 \pm 9,4$ & $79,9 \pm 8,6$ & $<0,001^{\mathrm{a}}$ \\
\hline Telogen \% & $27,7 \pm 9,4$ & $20,1 \pm 8,6$ & $<0,001^{\mathrm{a}}$ \\
\hline aWilcoxon işaret testi & & \\
\hline
\end{tabular}

orta; 2'si $(\% 3,8)$ zayıf olarak tanımlarken, hastaların 6'sı $(\% 11,3)$ tedavinin etkisiz olduğunu ifade ettiler. Hasta memnuniyeti ile frontal ve oksipital anagen değerlerindeki değişim oranları arasında, istatistiksel olarak anlamlı ilişki saptanmadı ( $p>0,05)$.

Yan etki profili açısından ilaç ile ilişkili istenmeyen 4 etki görüldü. Tedavi başında 1 hastamız bulantı; 1 hastamız dispeptik yakınmalar; 1 hastamız kötü koku hissi tarifledi. Bu bulgular tedavinin devamı ile geriledi ve tedavinin kesilmesini gerektirmedi. Bir hasta genel vücut kıllarında artış olduğunu ifade etti. Ancak klinik muayenede bu bulgu görülmedi.

\section{Tartışma}

Telogen effluvium kadınlarda görülen diffüz alopesinin en sık nedenlerindendir. Telogen effluvium kıl gelişim siklusundaki bozukluğa bağlı olarak aşırı miktarda telogen kıl kaybı sonucu gelişiri5,19,20.

Telogen effluvium telogen saçların yaygın kaybı ile karakterizedir. Olguların çoğu subklinik seyir gösterdiğinden gerçek insidansı bilinmemektedir21. Hastalar saç dökülmesi ile başvurduklarında saç dansitesi normal olarak değerlendirilebilir. Telogen effluviumda klinik olarak diffüz alopesi tanısı saçların en az \%25'i kaybedildiğinde konulabilir. Bu nedenle saç dökülmesinin ve verilen tedaviye cevabın değerlendirilmesinde yardımcı yöntemlere intiyaç duyulmaktadır22. Saç kaybının değerlendirilmesinde altın standart yöntem yoktur. İdeal inceleme yöntemi uygulaması kolay, tekrarlanabilir, ekonomik, noninvaziv olmalıdır ve saç gelişimi ile ilgili temel parametreleri verebilmelidir ${ }^{14}$. Kıl gelişim veya kıl kaybını değerlendirme metotları invaziv, semiinvaziv ve noninvaziv metotlar şeklinde 3 gruba ayrılabilir14,23,24. Çalışmamızda hastaların saç kaybının ve verilen tedaviye yanıııın değerlendirilmesinde günlük dökülen saç sayısı, saç çekme testi ve dijital fototrikogram kullanılmışıır. Saç çekme testi telogen effluviumda özellikle de akut telogen effluviumda pozitiftir ancak negatif çekme testi telogen effluviumu ekarte ettirmez ${ }^{6,25}$. Çalışmamızda tedaviye yanıtın değerlendirilmesinde kullanılan bir yöntem saç çekme testidir. Bu çalışmada tedavi öncesinde saç çekme testi hastaların 24'ünde $(\% 45,3)$ negatif, $29^{\prime}$ unda $(\% 54,7)$ ise pozitif saptanmıştır.

Literatürde tedavinin etkinliğinin trikogram yöntemi kullanılarak değerlendirildiği çok sayıda çalışma mevcuttur10,12,26-29. Trikogram yönteminin ağrılı olması, uygulayıcıya bağlı olması, 5 gün saçların yıkanmaması, taranmaması, bağlanmaması gerekliliği gibi sınırlandırıcı yönlerinin bulunması nedeniyle çalışmamızda tercih edilmemiştir. Dijital fototrikogram noninvaziv, ağrısız, kolayca tekrarlanabilen, 20 dakika gibi kısa sürede saç gelişimi ile ilgili parametrelerin ölçülebildiği, sonuçların bilgisayarda kaydedilebildiği, uygulayıcıdan bağımsız bir yöntemdir. İnce ve açık renkli saçların görünebilmesi için boya kullanılması gerekliliği ve saçın işlemden önce tıraşlanması ise yöntemin mevcut dezavantajlarıdır17,18,30,31. Çalışmamızda objektif değerlendirme metodu olarak dijital fototrikogram yöntemini tercih ettik. Tedaviye cevabı değerlendirmeye katkı için saç çekme testi ve günlük dökülen yaklaşık saç sayısı ile çalışmamızı destekledik.

Çalışmaya katılan hastaların \%90,6'sı dijital fototrikogram yöntemini güvenli ve hastayı tatmin edici bir yöntem olarak tanımlamıştır. Ancak literatürde bildirildiği gibi hastaların \%7, $5^{\prime} i$ tıraşlama, \%1,9'u 2 gün sonra kontrol gerekli olması nedeniyle dijital fototrikogramın saç dökülmesini araştırmada zaman alıcı bir yöntem olduğunu ifade etmişlerdir. 
Telogen effluviumun spesifik bir tedavisi yoktur. Saç dökülmesi tedavisinde genellikle vitamin ve aminoasit kombinasyonundan oluşan oral preparatlar kullanıı 7-9. Çalışmamızda hastalarımıza 3 ay süre ile 'darı ekstresi 140 mg, buğday tohumu yağı 271 mg, L-sistin 2 mg, kalsiyum pantotenat 10 mg' formulasyonu günde 3 kez 1 kapsül şeklinde verilmiştir.

Follikülden kıl yapımı hızlı keratin sentezini destekleyecek şekilde uygun dengede ve miktarda aminoasit alımı ve sağlanmasına bağıdır32. Birçok çalışmada koyunlarda yün liflerinin gelişimi ve kalitesinin beslenmeyle özellikle de sülfürlü aminoasitlerin düzeyleriyle ilişkili olduğu gösterilmiştir. Matheson ve arkadaşlarının kültüre edilen insan kıl follikülleri ile yaptıkları çalışmada follikül büyüme hızı, protein sentezi ve lif çapının sistinin bulunmasına bağlı olduğu saptanmıştır. Kültüre kıl folliküllerinde sistin konsantrasyonundaki azalmanın follikül büyüme hızı ve lif çapının azalması ile sonuçlandığı ve bu etkilerin geriye dönebilir olduğu belirtilmiştir33.

L-sistin saç dökülmelerinde tedavide sık kullanılan aminoasitlerden biridir. L-sistin doğal, alifatik aminoasittir ve keratin yapısında bulunur. Kıl \%15,9 oranında L-sistin içerir. Yapılan çalışmalarda L-sistinin kıl gelişiminde olumlu etkileri olduğu gösterilmiştir34-36. L sistin gibi sülfürlü aminoasitler protein sentezinde ve hücrelerin metabolik kapasitesinin korunmasında gereklidir37. L-sistin apoptozisi inhibe eder. Sadece $L$ sistin ve metionin biyolojik durumlarda geriye dönebilir oksidasyon/redüksiyon reaksiyonlarına girebilir, bu sayede oksidasyon/redüksiyon sinyal ve kontrolünde L sistinin önemli rolü vardır. Sigara ile indüklenen saç dökülmesinde L-sistin ve vitamin B6'nın koruyucu etkisi olduğu saptanmıştır36.

Pantotenik asit B grubu vitamin ailesinden suda çözünen bir vitamindir. D-pantotenat hücrenin koenzim A biyosentez yolunda ve dolayısıyla hücre fizyolojisinde önemli rol oynar. Pantotenat yara iyileşmesinde yaralanan bölgeye hücre migrasyonu ve proliferasyonunu sağlar37. Yeterli vitamin alımı özellikle epitelyal doku olmak üzere doku gelişimi için gereklidir. Eksikliğinin erken bulguları deride özellikle de deri eklerinde gözlenir. Saçlarda pigmentasyon kaybı ve alopesi görülebilir. Pantotenik asit kıl yapısının korunmasında önemlidir38.

Darı ekstresi içerisinde bulunan bir fitosterol miliasinin antiinflamatuvar etkisi vardır ve tamir mekanizmasını uyarır. Ayrıca antitoksik özellikleri vardır. Diyette fitosterollerin kan trigliserit düzeylerini düşürücü ve kanser gelişimini önleyici özellikleri olduğu düşünülmektedir37.

Obrigkeit ve arkadaşlarının yaptıkları çalışmada L-sistinin yüksek konsantrasyonlarda keratinositlerin metabolik kapasitesinde artmaya neden olduğu bildirilmiştir. Yine bu çalışmada hücre kültürüne pantotenat ve miliasin eklenmesiyle keratinositlerin metabolik kapasitesinde ve proliferasyonunda artma saptanmıştır. Ayrıca L-sistin, D-pantotenat ve miliasinin ayrı ayrı keratinosit kültürüne eklenmesine göre hepsinin bir arada eklenmesinin metabolik kapasitede ve keratinosit proliferasyonunda daha yüksek artışa neden olduğu bildirilmiştir37.

Dethlefs ve arkadaşlarının skarsız alopesisi olan kadın ve erkeklerden oluşan 19 hasta ile yaptıkları çalışmada, hastalara 'darı ekstresi 70 mg, buğday tohumu yağı 150 mg, L-sistin 1 mg, kalsiyum pantotenat 5 mg' içeren kapsül günde $3 \times 2$ dozunda 6 ay süre ile verilmiştir. Çoğunluğu androgenetik alopesili hastalardan oluşan ancak telogen effluviumlu hastaların da bulunduğu çalışma grubunda tedaviye yanıt trikogram ile anagen ve telogen oranlarında değişikliğe göre değerlendirilmiştir. On dokuz hastanın 14'ünde telogen oranında \%10 ve üzerinde düşme saptandığı, hiçbir hastada telogen oranlarında artma olmadığı bildirilmiştir. Çalışma sonucunda verilen formulasyonun diffüz alopesi tedavisinde faydalı olduğunu öne sürmüşlerdir ${ }^{10}$.

Gehring ve arkadaşlarının yaptığı randomize, çift kör, plasebo kontrollü çalışmada 'darı ekstresi, buğday tohumu yağı, L-sistin, kalsiyum pantotenat' formulasyonu veya plasebo, androgenetik alopesili kadın hastalara 6 ay süre ile günde 3 kez 2 kapsül şeklinde verilmiştir. Tedavi sonucunda aktif maddeyi alan grup fototrikogram ile değerlendirildiğinde anagen oranlarının \%85 ve üzerine çıktığı, plasebo grubunda ise \%85'e ulaşamadığı bildirilmiştir. Çalışma sonucunda darı ekstresi, buğday tohumu yağı, L-sistin, kalsiyum pantotenat' formulasyonun kadın androgenetik alopesi tipinde faydalı olduğunu göstermişlerdir35.

Bizim çalışmamızda bu iki çalışmadan farklı olarak androgenetik alopesili hasta bulunmamaktadır. Hastalarımıza darı ekstresi 140 mg, buğday tohumu yağı 271 mg, L sistin 2 mg, kalsiyum pantotenat 10 mg'dan oluşan kombinasyon günde 3 kez 1 kapsül şeklinde 3 ay verilmiştir. Çalışmamızda hastaların tedaviye verdikleri cevabın değerlendirilmesinde önceki 2 çalışmadan farklı olarak, dijital fototrikogram metodu ile anagen ve telogen düzeylerinin hesaplanması, saç çekme testi, günlük dökülen saç sayısı kriter olarak alınmıştır. Ayrıca hastaların tedaviden memnuniyeti sorgulanmış ve derecelendirilmiştir.

Çalışmamızda frontal bölgede ve oksipital bölgede tedavi sonrasında anagen oranındaki artma ve buna paralel olarak telogen oranındaki azalma istatistiksel olarak anlamlıdır $(p<0,05)$.

Tedavi sonunda frontal bölge anagen değerlerine göre 15 hastada $(\% 28,3)$ çok iyi yanıt gözlenirken, 17 hastada $(\% 32,1)$ tedaviye yanıt gözlenmemiştir. Oksipital bölge anagen oranları değerlendirildiğinde 15 hastada $(\% 28,3)$ çok iyi cevap gözlenmiştir, 16 hastada $(\% 30,2)$ ise tedaviye yanıt saptanmamıştır. Tedaviye rağmen telogen effluviumda ilerleme olan hastaların bulunması, verilen ilacın bu hastalarda etkisiz olması, ilaç dozunun ve süresinin yetersiz olması, hastaların genetik yapısı veya bilemediğimiz diğer çevresel faktörler ile ilişkili olabilir.

Hastalarımızın tedavi öncesi saç çekme testi ile tedavi sonrası saç çekme testi arasında istatistiksel olarak anlamlı farklılık saptanmıştır. Tedavi öncesi saç çekme testi hastaların \%54,7'sinde pozitif iken tedavi sonrasında bu oran \%5,7'ye gerilemiştir $(p<0,05)$.

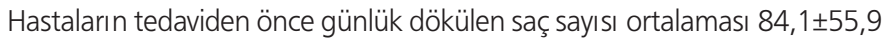
iken tedaviden sonra günlük dökülen saç sayısı ortalaması 44,9 28 olarak saptanmıştır. Tedavi sonrası günlük dökülen saç sayısındaki azalma istatistiksel olarak anlamlı bulunmuştur $(p<0,05)$.

Hasta memnuniyeti değerlendirildiğinde elde ettiğimiz bulgularla paralel olarak çalışmamıza katılan 53 hastanın 8'i tedaviyi saç dökülmesinde çok iyi; 23'ü iyi olarak tanımlamışlardır. Çalışmamızda hasta memnuniyeti ile frontal ve oksipital bölge anagen cevabı arasında ilişki saptanmamıştır. Bu durum hastaların objektif olmamaları ile ilişkili olabilir.

Tedavi ile frontal ve oksipital bölge anagen oranlarında anlamlı derecede artma, dökülen saç sayısında anlamlı derecede azalma ve saç çekme testinin negatifleşmesi gözlenmiştir. Bu bulgularla çalışmamızda L-sistin, kalsiyum pantotenat, buğday tohumu yağı ve darı ekstresinden oluşan formulasyonun telogen effluvium tedavisinde etkili olduğu sonucuna varılabilir. Telogen effluviumun kendiliğinden gerilediği ve vitamin, aminoasit kombinasyonlarının tedavide gerekli olmadığı bildirilmiş ise de çalışmamızda 3 aylık tedavi sonrasında hastalarımızın \%43,4'ünde frontal bölgede, \%49,1'inde oksipital bölgede iyi ve çok iyi yanıt alınmıştır. Tedavinin 6 aya uzatılması ile daha iyi sonuçlar elde edilebileceğine inanmaktayız. Plasebo ile karşılaştıılmamasına rağmen, uzun zamandır 
saç dökülme yakınması olan hastalarımızın 3 ay verilen tedavi ile şikayetlerinde gerileme olmasının telogen effluviumun kendiliğinden düzelmesi ile açıklanamayacağı düşünülebilir.

Literatürde çalışmamızla uyumlu olarak Budde ve arkadaşlarının tiamin,kalsiyum pantotenat, L-sistin içeren kombinasyon ile yaptıkları çalışmada ve Petri ve arkadaşlarının L-sistin ve kalsiyum pantotenat ile yaptıkları çalışmada anagen oranlarında artma şaptanmıştı ${ }^{12,29}$.

Literatürdeki çalışmalarla uyumlu olarak hastalarımıza verilen tedavi çok iyi tolere edilmiştir. Yalnızca 4 hastada tedavinin kesilmesini gerektirmeyen yan etki bildirilmiştir. L-sistin, kalsiyum pantotenat, darı ekstresi ve buğday tohumundan oluşan formulasyon, telogen effluviumlu kadın hastalarda kullanılabilen güvenli bir tedavi yöntemi olarak değerlendirilebilir.

Bu çalışmada elde ettiğimiz bulgular ile 'darı ekstresi, buğday tohumu yağı, L sistin, kalsiyum pantotenat formulasyonunun telogen effluvium tedavisinde faydalı olduğu sonucuna varılabilir. Ancak geniş hasta gruplarında plasebo kontrollü çalışmalar gereklidir.

Sonuç olarak çalışmamızda kullandığımız dijital fototrikogram yönteminin alopesili hastaların klinik takibinde ve verilen tedavinin etkinliğinin değerlendirilmesinde kullanılabilecek objektif ve etkili bir yöntem olduğunu düşünmekteyiz.

\section{Kaynaklar}

1. Springer K, Brown M, Stulberg DL: Common hair loss disorders. Am Fam Physician 2003;68:93-102.

2. Han A, Mirmirani P: Clinical approach to the patient with alopecia. Semin Cutan Med Surg 2006;25:11-23.

3. Wolff H: Diseases of hair. In: Burgdorf W.H.C, Plewig G, Wolff H.H, Landthaler M, Braun-Falco O, editors. Braun-Falco's Dermatology. 3rd ed. Italy: Springer, 2009; 1029-1059.

4. Serdaroğlu S, Oğuz O: Saç hastalıkları. Tüzün Y, Gürer MA, Serdaroğlu S, Oğuz O, Aksungur VL, editörler. Dermatoloji. 3. Baskı. İstanbul: Nobel Tıp Kitabevleri, 2008; 1295-1344.

5. Sinclair R: Diffuse hair loss. Int J Dermatol 1999;38 Suppl 1:8-18.

6. Shrivastava SB: Diffuse hair loss in an adult female: approach to diagnosis and management. Indian J Dermatol Venereol Leprol 2009;75(1):20-7; quiz 27-8.

7. Sperling LC: Alopecias. In: Bolognia JL, Jorizzo JL, Rapini RP, Callen JP, Horn TD, Mancini AJ, editors. Dermatology. 2nd ed. Spain: Mosby Elservier, 2008; 987-1005.

8. Odom RB, James WD, Berger TG: Andrew's Diseases of the Skin Clinical Dermatology. 9th ed. Philadelphia: WB. Saunders Company 2000; 946-947.

9. Sawaya ME: Novel agents for the treatment of alopecia. Semin Cutan Med Surg 1998; 17:276-83.

10. Dethlefs J, Scheneider W: Effect of a combination of vitamin and aminoacid on the hair growth. ZFA (Stuttgart) 1977;53:684-8.

11. Hertel H, Gollnick H, Matthies C, Baumann I, Orfanos CE: Low dosage retinol and L-cystine combination improve alopecia of the diffuse type following long-term oral administration. Hautarzt 1989;40:490-5

12. Budde J, Tronnier H, Rahlfs WW, Frei-Kleiner S: Systemic therapy of diffuse effluvium and hair structure damage. Hautarzt 1993;44:380-4.

13. Morganti P, Randazzo S, Bruno C: Effect of gelatin cystine on human hair. J Soc Cosmet Chem 1985;33:95-6.
14. Chamberlain AJ, Dawber RP: Methods of evaluating hair growth. Australas J Dermatol 2003;44:10-8.

15. Dhurat R: Phototrichogram. Indian J Dermatol Venereol Leprol 2006;72:242-4.

16. Wiedemeyer K, Schill WB, Löser C: Diseases on hair follicles leading to hair loss part 1: nonscarring alopecias. Skinmed 2004;3:209-14.

17. Hoffmann R: Trichoscan: Combining epiluminescence microscopy with digital image analysis for the measurement of hair growth in vivo. Eur J Dermatol 2001;11:362-8.

18. Hoffmann R: TrichoScan: A Novel tool for the analysis of hair growth in vivo. J Investig Dermatol Symp Proc 2003;8:109-15.

19. Özdemir M: Telogen effluvium. Turkiye Klinikleri J Int Med Sci 2006;2:6-9.

20. Harrison S, Sinclair R: Telogen effluvium. Clin Exp Dermatol 2002;27:389-95.

21. Oğuz $\mathrm{O}$, Küçüktaş $\mathrm{M}$ : Semptomatik saç dökülmesi tanı ve tedavisi. Turkiye Klinikleri J Cosm Dermatol-Special Topics 2008;1:1-8.

22. Fiedler VC, Hafeez A: Diffuse alopecia: Telogen hair loss. In: Olsen EA, editor. Disorders of Hair Growth Diagnosis and Treatment. 1st ed. New York: Mc Graw-Hill, 1994; 241-255.

23. Van Neste MD: Assesment of hair loss: clinical relevance of hair growth evaluation methods. Clin Exp Dermatol 2002;27:358-65.

24. Köşlü A: Saç Dökülmelerini Araştırma Yöntemleri. Galenos 1999;3:29-33.

25. Sperling LC: Hair and systemic disease. Dermatol Clin 2001;19:711-26, ix.

26. Peereboom-Wynia JD, van der Willigen AH, Stolz E: The effect of cyproterone acetate on hair roots and hair shaft diameter in androgenetic alopecia in females. Acta Derm Venereol 1989;69:395-8.

27. Brzezinska-Wcislo L: Effect of minoxidil on hair growth in androgenic alopecia in women. Pol Merkur Lekarski 2002;13:208-11.

28. Brzezinska-Wcislo L: Evaluation of vitamin B6 and calcium pantothenate effectiveness on hair growth from clinical and trichographic aspects for treatment of diffuse alopecia in women. Wiad Lek 2001;54:11-8.

29. Petri $\mathrm{H}$, Pierchalla $\mathrm{P}$, Tronnier $\mathrm{H}$ : The efficacy of drug therapy in structural lesions of the hair and in diffuse effluvium-comparative double blind study. Schweiz Rundsch Med Prax 1990;79:1457-62.

30. Hoffmann R: Trichoscan: What is new? Dermatology 2005;211:54-62.

31. Hoffmann R: A 4-month, open-label study evaluating the efficacy of eflornithine $11,5 \%$ cream in the treatment of unvanted facial hair in women using Trichoscan. Eur J Dermatol 2008;18:65-70.

32. Hynd PI, Nattrass G, Wilson N, Powell BC: Amino acid transport in wool and hair follicles. Exp Dermatol 1999;8:325-6.

33. Matheson HB, Westgate GE, Parmar PP et al: Nutrition and metabolism in isolated human hair follicles. Exp Dermatol 1999;8:319-20.

34. Karaca F, Önder M: Beslenmenin saçlar üzerindeki etkileri. Turkiye Klinikleri J Cosm Dermatol-Special Topics 2008;1:9-14.

35. Gehring W,Gloor M: Phototrichogram evaluation of hair growth products: results of a double-blind randomized study in women with androgenetic alopecia using an oral combination product of millet seed extract, L-cysteine, and calcium pantothenate, or placebo. Zeitschrift für Hautkrankheiten 2000;7-8:419-23.

36. D'Agostini F, Fiallo P, Penisi TM, Flora S: Chemoprevention of smoke-induced alopecia in mice by oral administration of L-cystine and vitamin B6. J Dermatol Sci 2007;46:189-98.

37. Obrigkeit DH, Oepen T, Jugert FK, Merk HF, Kubicki J: Xenobiotics in vitro: the influence of L-cystine, pantothenat, and miliacin on metabolic and proliferative capacity of keratinocytes. Cutan Ocul Toxicol 2006;25:13-22.

38. Fidanza A: Therapeutic action of pantothenic acid. Int J Vitam Nutr Res Suppl 1983;24:53-67. 